\title{
Emotions at Preschool Age: Contributions to Better Social and School Adaptation
}

\author{
Maria Regina Teixeira Ferreira Capelo ${ }^{1, *}$, John Miguel Costa Varela ${ }^{2}$, Noemí Serrano-Díaz ${ }^{3}$, \\ Maria Helena de Agrela Gonçalves Jardim ${ }^{4}$, Christina César Praça Brasil ${ }^{5}$, \\ Geraldo Bezerra da Silva Júnior ${ }^{5}$, Márcia Lúcia Sousa Dias Alves ${ }^{6}$ \\ ${ }^{1}$ Public Health, University of Fortaleza, Fortaleza, Brazil \\ ${ }^{2}$ Center for Lusophone and European Literatures and Cultures of Lisbon, Lisbon, Portugal \\ ${ }^{3}$ Didactic Department, University of Cádiz, Cádiz, Spain \\ ${ }^{4}$ Higher School of Health, University of Madeira, Funchal, Portugal \\ ${ }^{5}$ Medical Science Center, University of Fortaleza, Fortaleza, Brazil \\ ${ }^{6}$ Health Service of Autonomous Region of Madeira, Funchal, Portugal
}

Email address:

m.regina.capelo@gmail.com (M. R. T.F. Capelo)

${ }^{*}$ Corresponding author

\section{To cite this article:}

Maria Regina Teixeira Ferreira Capelo, John Miguel Costa Varela, Noemí Serrano-Díaz, Maria Helena de Agrela Gonçalves Jardim, Christina César Praça Brasil, Geraldo Bezerra da Silva Júnior, Márcia Lúcia Sousa Dias Alves. Emotions at Preschool Age: Contributions to Better Social and School Adaptation. Psychology and Behavioral Sciences. Vol. 8, No. 5, 2019, pp. 128-132.

doi: $10.11648 /$ j.pbs.20190805.14

Received: September 17, 2019; Accepted: October 5, 2019; Published: October 17, 2019

\begin{abstract}
Emotions have been triggering investigative interest for a long time due to the effect they have on people's lives and there is a growing importance in the educational field in the school context. The purpose of this study is to describe the relationship between perception, expression and appreciation of emotions and social adjustment of preschool children. For this purpose we used the documentary research based on four empirical works, carried out in Portugal $(\mathrm{n}=2)$ and Spain $(\mathrm{n}=2)$ between 2011 and 2016, resulting from the application of the "Percexval" test to assess the ability to understand, express and value emotions of preschool children (children aged $3-6$ years). The correct answers given by the children were confronted with the criteria of the external judges constituted by their kindergarten teachers. Results suggest significant and positive associations between perception of primary emotions and adaptation (2), control (3) peer acceptance (2) and negative with conflict; and significant and positive associations between perception and appreciation of primary emotions and adaptation (4), control (4), academic achievement (4), peer acceptance (2), and negatives with conflict. It is concluded that the promotion of early emotional education contributes to enhance the psychosocial adaptation of individuals.
\end{abstract}

Keywords: Emotions, Emotional Intelligence, Preschool Age

\section{Introduction}

Emotions, now universally recognized [1], have triggered investigative interest since antiquity [2-4] due to the crucial relevance in people's lives [4]. Defined as responses that guide behavior and provide information for the individual to achieve goals [5] a basic process with dynamic characteristics and adaptive functions, or as an intense reaction to a significant event for the individual, accompanied by physiological and psychological manifestations [6], which integrates a biological, cognitive and behavioral component, linked to subjective feelings of pleasure or pain [7]. This means that the brain processes all the emotional information captured by the senses. Concomitantly, they are influenced and influence the cognitive factors. That is, emotions produce motivating effects on conduct and influence perception, learning and performance, facilitating the adaptation of the person [8].

Signs of biologically programmed emotions such as 
disgust, interest, anguish, and satisfaction can be observed in newborns [3]. From two to seven months, the demonstration of new basic emotions such as sadness, anger, joy, surprise and fear can be seen; at the age of three, the child is able to assess their own emotions, and from the age of five, s/he reveals some emotional control [9].

The six basic emotions - joy, sadness, fear, surprise, anger and disgust, demonstrable in facial expressions, are alluded [10] as innate and universal, and may, in combination, give rise to more complex secondary emotions [11]. They assume a central role in the individual's life by greatly influencing mental processes and the content of cognition [12]. Therefore, recognizing the emotions expressed in the face is essential for human interaction [13]. This competence, integral to rational life, intervenes in the entire evolutionary process associated with social interaction, communication, information processing, attachment, moral development, among other dimensions, strongly influencing daily life and the decision-making process $[3,14,15]$. Emotions affect the learning process so their understanding in the educational context is relevant [3] especially at the earliest ages.

Studies conducted with socially disadvantaged children in classrooms with early childhood educators who establish high emotional and organizational quality interactions have shown that they reveal higher emotional regulation skills [16] This result corroborates the perspective of Mestre, Guil, Martinez-Cabanas, Larrán and Gonzales [17] when they assert that the development of the abilities implicit in the perception, expression and valorization of preschool children's emotions depends on the combination of cognitive and socio-emotional development. Therefore, according to the authors mentioned above, emotional education is fundamental. However, in early childhood it has been handed over to the family [18]. Hence, designed a comprehensive short-term emotional education program for children under the age of three to assess their effectiveness, especially the ability to perceive, evaluate and express basic emotions, as well as to analyze whether parental participation and of kindergarten teachers contributed to their development [18]. The results showed improved short-term emotional skills, especially in mothers, and confirmed the need for a more coordinated school-family relationship from the earliest ages to prevent possible risk factors and promote emotional health in early childhood.

There is evidence that adapting emotional education programs has an impact on emotional intelligence [18]. According to Mayer and Salovey [5], emotional intelligence results from the association of four competencies: the ability to perceive value and express emotions accurately; the ability to access and use emotional states and facilitate cognition; the ability to understand emotion, and the ability to manage emotions intentionally to promote emotional and intellectual growth. By proving to be a form of intelligence, and being considered fundamental to a better relationship with peers, to more success in developing positive attitudes in school adaptation and academic achievement, the topic of emotions has benefited from increasing importance in the educational field in the school context.

The growing recognition of the importance of emotions has been awakening the need to construct instruments to measure objectively this construct. Noting the lack of valid and reliable measuring instruments to evaluate the effectiveness of intervention programs, Mestre and collaborators [17] developed the one instrument to measure the ability to perceive, express and value emotions in the preschool stage. Simultaneously measuring the personal and social adaptation of children which was later applied to Portuguese children [19, 20], and the results obtained revealed similarities. Thus, the purpose of this study is to describe the relationship between perception, expression and appreciation of emotions and social adjustment of preschool children.

\section{PRECEXPVAL: Exam to Assess Children's Ability to Perceive, Express and Value Emotions in Preschool Stage}

This study is a research of empirical studies that deal with emotions in preschool age and seeks to answer the following question:

Is there a relationship between the perception, expression and appreciation of emotions and the social adjustment of preschool children?

The strategy of obtaining data was the systematic and explicit search for empirical studies that present results from the application of the test called PRECEXPVAL test, to evaluate the perception and appreciation of emotions of preschool children [17]. It is a test developed in the Emotional Intelligence Laboratory of the University of Cadiz, by José Miguel Mestre Navas and collaborators, in PowerPoint, to be presented on screen to children from 3 to 6 years old. In this test, the children are asked to mark on the screen the answer they consider appropriate according to the instructions presented on each type of slide. The first type of slide corresponds to the subscale of basic emotions, contemplates items $1,3,5,7,9,11,13,15$, and the children must indicate before six hypotheses (six faces representing different facial expressions) on each slide, the expression that a character Alex named should put in a certain situation. The second type seeks to assess more ambiguous situations, encompassing items 2, 4, $6,8,10,12,14,16$, and the child has to discriminate between two identical characters, which one is most likely to feel emotion in a cast of three possible answers (twin sisters: Cris and Tina or neither). The latter situation requires the child's perception and appreciation and effort to judge which one fits the question. The sixteen test items are:

1) Can you indicate the face that Alex would look if he were sad because the teacher had a fight with him in class?

2) Which of the young women is angry because they were told something they did not like? Cris, Tina or neither?

3) Alex was sleeping and woke up with a loud noise. It was dark in the room and scared. What face do you think he put?

4) Which of the two do you think is saddest? Cris, Tina or 
neither?

5) Alex is angry because his friend has a new game but doesn't want to borrow it. What face do you think he put?

6) Which of the two do you think is saddest? Cris, Tina or neither?

7) What face do you think Alex showed if he felt lonely and sad because no one wanted to play with him in the playground?

8) Which of the two do you think is very afraid? Cris, Tina or none of them?

9) Alex is angry because his older brother spoiled his favorite game. What face do you think he put?

10)Which of the two do you think is very surprised? Cris, Tina or neither?

11)Alex is happy with his birthday party. What face do you think he put?

12)Which of the two do you feel disgusted? Cris, Tina or neither?

13)Alex comes home to find a party he didn't expect, hosted by his mother, and is a little surprised What face do you think he put?

14)Which of the two do you think is most cheerful? Cris, Tina or neither?

15)Today, they offered lunch a meal that Alex hated and felt disgusted with. What face do you think he put?

16)Which one is less sad? Cris, Tina or neither?

On slides, possible answers include emotional labels - joy, sadness, fear, anger, surprise and disgust and never appear in the same order. The test application has no time limit and the answers are noted on the examiner's observation sheet, which contains the child's name, age, gender and school.

The child's school adaptation is measured from the response of the respective kindergarten teachers given in a six-point Likert scale questionnaire (1 corresponds to nothing or almost nothing and 6 corresponds to completely), with 5 questions. These assess various aspects related to the child's school adaptation, such as school adaptation, impulse control, academic achievement, peer acceptance level and level of conflict:

1) What is the child's level of adaptation to school?

2) What is the child's impulse control level?

3) What is the child's academic achievement level?
4) What is the peer acceptance level of this child?

5) What is the level of conflictivity of the child?

The correlation of the responses to PERCEXPVAL given by the children with the established external criteria, expressed in the representations of the kindergarten teachers about the participants, try to evidence the perception and valorization of the emotional expressions and the school adaptation in this stage of the developmental cycle, as follows: descriptive and interpretative scope review.

\section{Results and Discussion}

This study on the relationship between the perception, expression and appreciation of emotions and the social adjustment of preschool children evokes empirical work that used the "Precexval para niños". The review of the scope contributes to highlighting a proof that, although it is evolving [17] seems to clarify some questions posed in its genesis. This, although in its developmental phase, was cross-culturally adapted to Portuguese and its applicability proved adequate [21]. This research included only empirical studies that used the application of "PRECEXVAL para niños" [17], published in Spanish or Portuguese and involving as participants children of pre-school education, from any socio-geographic and / or cultural context $[17,22,19,20]$.

This scope review does not foresee the exclusion of studies according to methodological criteria, but identify common categories that allow discursively synthesizing the findings through the application of the same instrument in participants who fall in the age group 3 - 6 years and who attend preschool education. Study characterization data were extracted, such as authorship, date and geographic context of application of the instrument and number of participants. The focus is on the relationships found between the participants 'responses and the external judges' assessment. The review included four empirical studies conducted in different geographical contexts, namely Spain (2) and Portugal (2). The number of participants varies between 138 and 455 and the publications took place between 2011 and 2016. Tables 1, 2, 3 and 4, shows a synoptic characterization of these studies.

Table 1. Correlations between subscales and overall PERCEXVAL score for children and the established criteria (17).

\begin{tabular}{|c|c|c|}
\hline Study & Validation of a test to assess the ability to perceive, express and assess emotions in children of the & hild stage \\
\hline Authors & Results & Classification \\
\hline $\begin{array}{l}\text { Mestre, et al. } \\
\text { (2011) } N=138\end{array}$ & $\begin{array}{l}\text { The perception scale of emotional expressions does not reveal significant results with the perception } \\
\text { of the kindergarten teachers. }\end{array}$ & \\
\hline $\begin{array}{l}\text { Context: Cádiz, } \\
\text { Spain }\end{array}$ & $\begin{array}{l}\text { The subscale perception and valorisation of emotional expressions reveals a significant association } \\
\text { with the perception of kindergarten teachers, being positive regarding the child's level of adaptation to } \\
\text { school }(\mathrm{r}=-0.2855 ; \mathrm{p}<0.01) \text {; impulses }(\mathrm{r}=-0.206 ; \mathrm{p}<0.05) \text {, the level of academic achievement }(\mathrm{r}= \\
-0.326 ; \mathrm{p}<0.01) \text { and negative association regarding the level of conflict }(\mathrm{r}=-0.216 ; \mathrm{p}<0.05) \text {. }\end{array}$ & $\begin{array}{l}\text { Adaptation; Control; } \\
\text { Academic performance; } \\
\text { Less conflictivity }\end{array}$ \\
\hline
\end{tabular}

Table 2. Correlations between subscales and overall PERCEXVAL score for children and the established criteria (22).

\begin{tabular}{|c|c|c|}
\hline Study & $\begin{array}{l}\text { A correlational study between emotional knowledge, verbal intelligence and gender in school adapta } \\
\text { education }\end{array}$ & ion in children of child \\
\hline Authors & Results & Classification \\
\hline $\begin{array}{l}\text { Wertz }(2014) N= \\
455\end{array}$ & $\begin{array}{l}\text { The subscale Perception of Emotional Expressions reveals significant associations with the perception of } \\
\text { kindergarten teachers being positive about the child's school adaptation }(\mathrm{r}=0.160 ; \mathrm{p}<0.01) \text {, impulse } \\
\text { control }(\mathrm{r}=0.141 ; \mathrm{p}<0.01) \text {, academic performance }(\mathrm{r}=0.129 ; \mathrm{p}<0.01) \text { and negative association with }\end{array}$ & $\begin{array}{l}\text { Adaptation; Control; } \\
\text { Academic performance; } \\
\text { Less conflictivity }\end{array}$ \\
\hline
\end{tabular}




\begin{tabular}{|c|c|c|}
\hline Study & $\begin{array}{l}\text { A correlational study between emotional knowledge, verbal intelligence and gender in school adapta } \\
\text { education }\end{array}$ & ion in children of child \\
\hline Authors & Results & Classification \\
\hline $\begin{array}{l}\text { Context: Cádiz, } \\
\text { Spain }\end{array}$ & $\begin{array}{l}\text { conflict }(\mathrm{r}=-0.099 ; \mathrm{p}<0.05) \text {. } \\
\text { The subscale perception and valorisation of emotional expressions reveals a significant association with } \\
\text { the perception of kindergarten teachers, being positive regarding the child's level of adaptation to school } \\
(\mathrm{r}=0.153 ; \mathrm{p}<0.01) \text {, the impulsivity control }(\mathrm{r}=0.128 ; \mathrm{p}<0.01) \text {, academic achievement }(\mathrm{r}=0.218 ; \mathrm{p}< \\
0.01) \text { and peer acceptance }(\mathrm{r}=0.098 ; \mathrm{p}<0.05) \text {. }\end{array}$ & $\begin{array}{l}\text { Adaptation; Control; } \\
\text { Academic performance; } \\
\text { Peer acceptance. }\end{array}$ \\
\hline
\end{tabular}

Table 3. Correlations between subscales and overall PERCEXVAL score for children and the established criteria (19).

\begin{tabular}{|c|c|c|}
\hline Study & Pre-validation of a preschool emotion test & \\
\hline Authors & Results & Classification \\
\hline $\begin{array}{l}\text { Magalhães (2015) } \\
N=164\end{array}$ & $\begin{array}{l}\text { The perception and valorisation of emotional expressions subscale reveals significant associations with } \\
\text { the perception of kindergarten teachers being positive about the child's school adaptation }(\mathrm{r}=-0.222 ; \mathrm{p}< \\
0.01) \text {, impulse control }(\mathrm{r}=-0.198 ; \mathrm{p}<0.05) \text {, academic achievement }(\mathrm{r}=-0.259 ; \mathrm{p}<0.01) \text {, peer } \\
\text { acceptance }(\mathrm{r}=-0.209 ; \mathrm{p}<0.01) \text { and negative association with conflict }(\mathrm{r}=-0.189 ; \mathrm{p}<0.05) \text {. }\end{array}$ & $\begin{array}{l}\text { Adaptation; Control; } \\
\text { Academic performance; } \\
\text { Less conflictivity }\end{array}$ \\
\hline $\begin{array}{l}\text { Context: Madeira, } \\
\text { Portugal }\end{array}$ & $\begin{array}{l}\text { The perception and valorisation of emotional expressions subscale reveals significant associations with } \\
\text { the perception of kindergarten teachers being positive about the child's school adaptation }(\mathrm{r}=-0.222 ; \mathrm{p}< \\
0.01) \text {, impulse control }(\mathrm{r}=-0.198 ; \mathrm{p}<0.05) \text {, academic achievement }(\mathrm{r}=-0.259 ; \mathrm{p}<0.01) \text {, peer } \\
\text { acceptance }(\mathrm{r}=-0.209 ; \mathrm{p}<0.01) \text { and negative association with conflict }(\mathrm{r}=-0.189 ; \mathrm{p}<0.05) \text {. }\end{array}$ & $\begin{array}{l}\text { Adaptation; Control; } \\
\text { Academic performance; } \\
\text { Less conflict. }\end{array}$ \\
\hline
\end{tabular}

Table 4. Correlations between subscales and overall PERCEXVAL score for children and the established criteria (20).

\begin{tabular}{|c|c|c|}
\hline Study & Assessment of the ability to perceive, express and value emotions in preschool children & \\
\hline Authors & Results & Classification \\
\hline $\begin{array}{l}\text { Romão (2016) } N= \\
374\end{array}$ & $\begin{array}{l}\text { The subscale Perception of Emotional Expressions reveals significant associations with the perception } \\
\text { of kindergarten teachers being positive about the child's school adaptation }(\mathrm{r}=0.162 ; \mathrm{p}<0.01) \text {, } \\
\text { impulse control }(\mathrm{r}=0.138 ; \mathrm{p}<0.01) \text {, academic achievement }(\mathrm{r}=0.317 ; \mathrm{p}<0.01) \text {, peer acceptance }(\mathrm{r} \\
=0.163 ; \mathrm{p}<0.01) \text { and negative association with conflict }(\mathrm{r}=-0.242 ; \mathrm{p}<0.01) \text {. }\end{array}$ & $\begin{array}{l}\text { Adaptation; Control; } \\
\text { Academic performance; } \\
\text { Peer acceptance; Less } \\
\text { conflictivity }\end{array}$ \\
\hline $\begin{array}{l}\text { Context: Madeira, } \\
\text { Portugal }\end{array}$ & $\begin{array}{l}\text { The subscale perception and valorisation of emotional expressions reveals significant associations } \\
\text { with the perception of kindergarten teachers being positive regarding the child's school adaptation }(\mathrm{r}= \\
0.214 ; \mathrm{p}<0.01) \text {, impulse control }(\mathrm{r}=0.162 ; \mathrm{p}<0,01) \text {, academic performance }(0.335 ; \mathrm{p}<0.01) \text {, peer } \\
\text { acceptance }(\mathrm{r}=0.204 ; \mathrm{p}<0.01) \text { and negative association with conflict }(\mathrm{r}=-0.228 ; \mathrm{p}<0.01) \text {. }\end{array}$ & $\begin{array}{l}\text { Adaptation; Control; } \\
\text { Academic performance; } \\
\text { Peer acceptance; Lowest } \\
\text { conflictivity }\end{array}$ \\
\hline
\end{tabular}

Only the study by Mestre and collaborators [17] does not present a significant association between the perception of emotions subscale and the evaluation of external judges, making it difficult to assure if the different results can be related to context factors such as the socioeconomic and cultural environment or where the child, the family intervention or the type of school (public or private) and their educational programs are inserted [18]. There is evidence explained by constructivist theories that advocate a cultural approach by claiming that emotions are socially constructed [23-25]. Others investigators [26] also point out that children from private schools get higher scores on emotional skills. In turn, investigations $[22,19,20]$ indicated relationships of relevant statistical significance concerning the control dimension, academic performance and lower conflict, revealing the crucial role of valuing emotions in this stage of the study. Still, regarding the valuation subscale of emotions, the results also suggest adaptation $[22,20]$ and acceptance by peers [20].

The impact of emotional functioning on survival, adaptability, sociability and learning is unquestionable [1]. Emotions guide and support attentional functions, capture attention and aid memory, and help how mental states influence cognitive and executive functions, and play a key role in interactions. In this sense, the four studies [17, 19, 20, 22] show a significant association between the perception and valuation of emotions subscale and the criteria of external judges regarding adaptation, control and academic performance. Acceptance by peers emerges [20, 22], while lower conflict stands out in the work [17, 19, 22], inferring from this that the pre-school is crucial for children to develop new ways of expressing themselves and relating to others.

From this perspective, emotions can be perceived as disruptive or driving forces of cognition, which suggests the need for regulation, suppression and control in the interest of producing creative responses adapted to everyday situations. However, since it is not easy to assess emotional intelligence at preschool age, PERCEPXVAL for children, supported by the Salovey and Mayer [27] model of emotional intelligence, although still evolving and evolving, has filled the gap in this domain, useful for assessing the ability to perceive, express, and value emotions at this stage of the life cycle.

\section{Conclusions}

This study aimed to describe the relationship between the perception, expression and appreciation of emotions and social adjustment of preschool children from studies that used PERCEPXVAL for children as a measuring instrument. The analysis of the scientific production raised, showed evident evidences in the correlations between the subscales and the criteria of the external judges that corroborate the theoretical model that perceiving/valuing the emotions is fundamental for a better psychosocial adaptation.

The literature research revealed a scarcity of scientific research on emotions centered on the earliest and most 
crucial stages of human life, such as the preschool one (3 - 6 years), at an age when the child crosses family boundaries and begins socialization with peers.

In view of this scenario, it is suggested to implement preschool emotional education programs that, in addition to education professionals, may also involve families, believing that the enhancement of early emotional education will have a positive impact throughout the life of the child: individual learning, interpersonal relationships, adaptation, impulse control and appropriate coping with the challenges that life presents.

\section{References}

[1] Fonseca, V. Importância das emoções na aprendizagem: uma abordagem neuropsicopedagógica. Revista Psicopedagogia, Vol. 3, No. 102, 2016, pp. 365-384.

[2] Alves, C. M. G. Inteligência emocional em crianças com dificuldades de aprendizagem: uma perspetiva educativa. Dissertação de Mestrado. Escola superior de Educação João de Deus, 2013.

[3] Jesus, R. M., \& Lempke, N. N. S. Manifestações emocionais das crianças na educação infantil. SynThesis Revista Digital FAPAM, Vol. 6, No. 6, 2015, pp. 309-325.

[4] Tirri, K., Nokelainen, P., \& Komulainen, E. Multiple intelligences: Can they be measured? Psychological Test and Assessment Modeling, Vol. 55, No. 4, 438-461, 2013.

[5] Mayer, J. D. \& Salovey, P. Que és inteligência emocional? In J. M. Mestre e Fernández-Berrocal (Eds.), Manual de Inteligência Emocional. Madrid: Pirâmide, 2007, pp. 2545 .

[6] Freitas-Magalhães, A. A psicologia das emoções: O fascínio do rosto humano. Lisboa: Leya, 2013.

[7] Moors, A. On the causal role of appraisal in emotion. Emotion Review, Vol. 5, 2013, pp. 356-368.

[8] Mestre, Navas, J. M \& Guil Bozal, R. Regulación de emociones. Uma vía a la adaptación personal y social. Madrid: Pirámide, 2012.

[9] Shaffer, D. R. \& Kipp, K. Psicologia do desenvolvimento: infância e adolescência. São Paulo: Cengage Learning, 2012.

[10] Ekman, P. Emotions Revealed: recognizing faces and feelings to improve communication and emotional of findings. London: Elsevier, 2007.

[11] Izard, C. More meanings and more questions for the theme "Emotion". Emotion Review, Vol. 2, No. 4, 2010, pp. $383-$ 385 .

[12] Leite, M. L. L. C. Ação pedagógica e desenvolvimento da inteligência emocional na infância: reflexão e partilha de uma prática. Dissertação de Mestrado. Escola Superior de Educação Paula Frassinetti, 2014.

[13] Aguiar, J. S. R., Silva, A. I. P., Aguiar, C. s. R., N., Souza, W. C. A influência da intensidade emocional no reconhecimento das emoções em faces por crianças brasileiras. Universitas Psychologica, Vol. 15, No. 5, 2016, pp. 206-215.

[14] López Cassá, E. La educación emocional en la educación infantil. Revista Interuniversitária de Formación del Profesorado, Vol. 16, No. 3, 2005, pp. 153-167.

[15] Lopatovska, I. \& Arapakis, I. Theories, methods and current research on emotions in library and information science, information retrieval and human-computer interation. Information Processing \& Management, Vol. 47, No. 4, 2011, pp. 575-592.

[16] Cadima, J., Ferreira, T., Guedes, C., Vieira, J., Leal, T. P. M. Risco e regulação emocional em idade pré-escolar: a qualidade das interações dos educadores de infância como potencial moderador. Análise Psicológica, Vol. 34, No. 3, 2016, pp. 235-248.

[17] Mestre, J. M., Guil, R., Martínez-Cabanas, F., Larrán, C., \& González, GG. Validación de uma prueba para evaluar la capacidade de percibir, expressar y valorar emociones em niños de la etapa infantil. Revista electrónica interuniversitária de formación del professorado, Vol. 14, No. 3, 2011, pp. 3754 .

[18] García Tárraga, M. J. Eficacia de um programa integral de educación emocional para menores de três años. In Juan-Luis Castejón Costa (Coord.). Psicología y Educación: Presente y Futuro, CIPE2016, 2016, pp. 1414-1421.

[19] Magalhães, S. G. Pré-validação de um teste de emoções na idade pré-escolar. Dissertação de Mestrado em Psicologia da Educação. Universidade da Madeira, 2015.

[20] Romão, A. S. Avaliação da capacidade de perceber, expressar e valorizar emoções nas crianças em idade pré-escolar. Dissertação de Mestrado em Psicologia da Educação. Universidade da Madeira, 2016.

[21] Capelo, R., Varela, M, \& Serrano-Díaz, N. Perceção, expressão e valorização das emoções das crianças na educação pré-escolar. Revista Exitus, Vol. 8, No. 2, 2018, pp. 137-162.

[22] Wertz, V. Un estúdio correlacional entre el conocimiento emocional, la inteligência verbal y el género em la adaptación escolar de niños/as de Educación infantil. Monografía de Grado de Educación Infantil. Universidad de Cádiz, 2014.

[23] Gendron, M., Roberson, D., Van der Vyer, J. L. Perceptions of emotion from facial expressions are not culturally universal: evidence from remote culture. Emotion, Vol. 14, No. 2, 2014, pp. 251-262.

[24] Jack, R. E., Garrod, O. G., Yu, H., Caldara, R. \& Schyns, P. G. Facial expressions of emotion are not culturally universal. Procedings of the National Academy of Sciences, Vol. 109, No. 19, 2012, pp. 7241-7244.

[25] Lindquist, K., Siegel, E., Quigley, K. \& Barret, L. The hundred-year emotion war: are emotions natural kinds or psychological construction? Comment on Lench, Flores, and Bench. Psychological Bulletin, Vol. 139, No. 1, 2013, pp. 255263.

[26] Ricarte, M. D., Minervino, C. M., Roazzi, A., Dias, M. G. \& Viana, D. N. M. Examining the link between preschool socialemotional competence and first grade academic achievement: the role of attention skills. Early childhood. Research Quarterly, Vol. 26, No. 2, 2009, pp. 182-191.

[27] Salovey, P., \& Mayer, J. D. Emotional Intelligence. Imagination, Cognition and Personality, Vol. 9, No. 3, 1990, pp. 185-211. 